\title{
Issues of Applying Anti-Corruption Legislation in Criminal Investigation and Court Trial in the Russian Federation
}

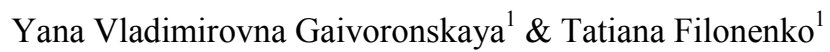 \\ ${ }^{1}$ Law school, Far-Eastern Federal University, Russian Federation \\ Correspondence: Yana Vladimirovna Gaivoronskaya, Law school, Far-Eastern Federal University, Russian \\ Federation. E-mail: yannavlad@gmail.com
}

Received: September 10, 2014

Accepted: September 16, 2014 Online Published: October 30, 2014

doi:10.5539/ass.v10n21p236

URL: http://dx.doi.org/10.5539/ass.v10n21p236

\begin{abstract}
Corruption problems in modern Russia are still very accute. A lot has been done to change the situation and to lower the corruption level in the country, but lots of scholars and experts are sure that some mechanisms still have much to be desired.

This paper examines the main means of fighting corruption in Russia nowadays and the main problems the state faces while investigating and prosecuting such crimes. The author creates his own conception of dealing with investigation of corruption crimes and makes some suggestions about changing anti-corruption legislation.
\end{abstract}

Keywords: corruption, investigation practice, corruption crimes, preventive measures

\section{Introduction}

Anti-corruption campaign in Russia began in 2008 when in December Dmitry Medvedev signed the Federal Law "Fight Against Corruption". Very much has changed since then except one thing: still the key word of the reports saying about an average bribe in Russia is the word "increase". For the last 6 years an average bribe has become more than 16 times larger, from 9000 to 145000 rubles. In 2013 Russian corruption (38600 corruption crimes) caused the country a damage of more than 21 billion rubles. The method of calculating an average bribe was changing in that time: since 2011 the General Department of Economic Security and Anti-Corruption Activity began to inform not only about an average bribe (taking into account an "everyday" corruption of citizens) but about an average commercial bribe as well. According to the Transparency International, Russia takes the $127^{\text {th }}$ position of 175 in the index of perception of corruption. In 2012 it took the 133 position of 174 countries (Note $1)$.

One of the main tasks, set by the President of the Russian Federation for the nearest future, is the activity against corruption in the state power and government and protection of national property from criminality. According to the official statistics, in the process of realization of this task within 9 months of the year 2013, investigators had about 30000 criminal anti-corruption cases, which means 4000 more than the whole previous year. The investigation of 9280 criminal cases was completed, 7861 cases were committed to the court (Note 2). In the result more than 11000 people were brought to trial, and according to the Ministry of Interior Affairs an average bribe taken counted 851000 rubles (Note 3). The trial is still going on and people are waiting for the verdict in prisons.

In spite of the fact that the ways and methods of anti-corruption combat have been improved for the past years, the problems of exposing and investigating such crimes are still very urgent. Set by the President task of complex fight against corruption in the country is still likely to demand new forces and means as well as improving the legislation.

Let's look at the problems of applying the anti-corruption law in Russia in detail.

\section{Research Methodology}

This research is done with the help of statistics, analysis of cause and effect, sociological examination and comparative law analysis. The article exposes main problems which the law-enforcement agencies face while trying cases from this category in courts, provides the analysis of the statistics allowing to make some conclusions and proposals to improve the legislation in this sphere. 


\section{Results and Discussion.}

One of the features of investigating such crime is a high extent of non-visuality The image of corruption fixed by the statistics is far from reality if not to take into consideration a high level of latent bribery and other corruption actions. Criminologists estimate that less than 1 per cent of really committed corruption crimes are revealed and registered (Kuzenkov, 2009). Consequently, the majority lies beyond the sphere of law-enforcement agencies. A reason for this is the fact that corruption always represents a deal between an official and a person concerned in his definite behavior (Nomokonov, 2009).

It follows that a briber, as well as a bribetaker, are both satisfied with the way to settle some problem, so there appears no need to apply to law enforcement agencies in this connection, and, in the result, this corruption deal is closed for everybody except for its direct participants.

It should be noted that in a case of bribery, for example, it's very difficult to prove anything if a party is unwilling to collaborate. In order to succeed in practical investigation, someone should report about "a cover" (a bribe), moreover, to report in advance, because after taking a bribe it's impossible to prove anything. To prosecute a criminal case in court there must be serious evidence, like the materials of the investigation, records of conversations, video records, marked banknotes, etc. If a person states he/she gave a bribe and another one denies this, and there is no other evidence except the testimony of the victim, to bring an accusatory verdict is impossible. An ideal option is that before an action of bribery one participant informs the law enforcement agencies about it and they have enough time to realize a combination of crime detection actions. In the majority of cases, people, as a rule, prefer to settle their problems peacefully and inform the police only in case of emergency.

The Supreme Court published court statistic data of Russia in 2013, and corruption cases as well. Judging by the figures, a paradoxical situation is evident in Russia: the citizens actively give bribes, but the officials almost do not take them. Thus, more than 1300 persons were convicted for bribe giving, but only 544 officials were convicted for bribe taking. Experts are not surprised with this situation and say that anti-corruption fight is often substituted with profanation: instead of catching bribe-takers in official agencies the law-enforcement bodies make corruption statistics at the expense of petty bribe-givers, like drivers, migrants, merchants, who try to pay off by the sums from 500 to 5000 rubles. This exists because to prove corpus delicti in case of this civil category is much easier than to sue a dishonest official for corruption.

Due to gaps and flaws of the legislation as well as the difficulty to legalize information about investigation, corruption activity is often impossible to prove. It's quite typical for investigation to have enough grounds to suppose that criminal actions were committed by definite persons but the data available is not sufficient to bring an accusation. In this situation to solve the problem of effective struggle against corruption seems to be hardly possible with traditional means only, without working out and enforcing into law enforcement practice new contemporary methods. Taking into consideration that corruption crimes are revealed mainly through operative crime detection, the issue in general means improving the activity of crime detection agencies.

The analysis of crime and results of investigation demonstrates committed tactical errors and violations done during crime detection operations. The decisions made on the basis of preliminary inquiries directly depend on the quality of investigating operations, on the strict accordance with the provisions of the Federal Law "On the Operative Crime Detection Activities", because violation of the law on this stage results in further declaration of the collected evidence invalid.

Besides, corruption crimes are considered to be complicated in investigating and collecting the evidence, that is why to investigate such cases, well-trained and qualified investigation agents are needed, who major in detection and investigation of such crimes.

One more important problem is that the Criminal Procedure Code of the Russian Federation determines additional procedural guarantees in relation to a wide variety of officials, stipulated in Article 447 of the Criminal Procedure Code of the Russian Federation. According to this clause, a category of persons to whom a special criminal procedure is used, includes the following: a member of the Federation Council and a deputy of the State Duma, a deputy of the legislative (representative) agency of a constituent entity of the Russian Federation, a deputy, member of a local self-government entity, an elected official of a local self-government entity; judges of the Constitutional Court of the Russian Federation, judges of the courts of the first instance or federal arbitration court, judges of the peace and judges of the constitutional courts of a constituent entity of the Russian Federation, a juror or an arbitrage juror during the trial; the Chairman of the Account Chamber of the Russian Federation, his deputy and auditors of the Account Chamber of the Russian Federation; a Commissioner on Human Rights in the Russian Federation; the President of the Russian Federation who stopped exercising his 
duties ,as well as the candidate to the President of the Russian Federation; a prosecutor; the Head of the Investigation Committee of the Public Prosecution Office of the Russian Federation; a head of investigation agency; an investigator; a lawyer; a member of elective committee, of a referendum committee; a registered candidate to the State Duma deputies, a registered candidate to the legislative (representative) body of a constituent entity of the Russian Federation. This special procedure includes some privileges for the categories mentioned above.

In reality these stipulated by the law "advantages" often appear to be an insuperable obstacle for law-enforcement bodies and sometimes exclude a chance to bring to criminal trial the persons mentioned above. To possess such "immunity" is a great desire for persons involved in a criminal activity, corruption among them. The civil public has been concerned about this situation for a long time, and it's not accidental that, among the main trends of federal agencies' anti-corruption activity stated by the President, there emerged a proposal of "reducing the category of persons to whom a specific order of criminal procedure and crime detection activity is applied" (Grigoriev, 2009).

It seems that the law-makers should introduce the corresponding amendments into the law.

Set by the President task of complex anti-corruption struggle in the country demands a definite amendment of not only the criminal process legislation but of the criminal legislation as well.

For example, seizure of property as a form of criminal law force in the Criminal Code of the Russian Federation is not effective enough. Contrary to the expectations, seizure is not used in the cases of larceny, tax crimes, etc. The author of this research suggests that seizure of property should be returned to the Criminal Code of the Russian Federation as a kind of punishment introduced as a sanction for corruption crimes, as this exact punishment has a maximum effectiveness and meets not only the requirements of anti-corruption activity but the interests of the country which will have an opportunity to take back in the federal budget everything got due to the corruption, i.e. illegally. The most severe punishment for a person who committed corruption crime is not a huge fine or probationary sentence but a fear to be deprived of all wealth he and his family owns.

To prove that let's demonstrate some figures. According to the official statistics, given by Yu.Ya. Chaika, the RF Prosecutor General, in 2013 the corruption damage added to the sum of 21 billion rubles (Note 4), but only 2 billion was charged back to the national budget. These figures confirm the fact that anti-corruption struggle in Russia is still not that successful as it is expected.

In order to undermine the motivation and material basis of corruption it seems perspective to apply to the institutions and norms of civil law. In this connection, a civil law institution of "duties due to a harm inflicted" (Art.1064-1083, Chapter 59, Part II of the Civil Code) is of special interest. It is used to enforce corrupted officials to fully or partially compensate a material damage, inflicted to the state or municipal corporations as a result of power decisions, made by them due to mercenary interests, and these decisions are deliberately unfavorable for the state and local self-government body (illegal governmental acts). According to Part I, Art.45, the Civil Procedure Code of the Russian Federation, a prosecutor is empowered to apply to court with a claim to protect the legal rights of indefinite persons and the interests of the Russian Federation, of constituent entities and of municipal corporations. Besides, in accordance with Art.44 of the Civil Procedure Code of the Russian Federation suit of damage can be commenced on a corrupt official by the prosecutor during a criminal investigation and criminal trial. A commence of such suits during a criminal investigation or after the trial seems to be of national importance.

Moreover, at present there is enough court practice in satisfaction prosecutor's suits to charge from a corrupt official the sum of inflicted damage. Not long ago the Chita Central district court by the suit of deputy prosecutor of Zabaikalsky territory obliged Vyacheslav Korlokov, a former head of Regional Department of Emergency Control Ministry of Russia, and his subordinates to pay 9,2 million rubles to compensate the sum of bribes got by them. A similar suit was produced by Arkhangelsk territory public prosecution to a former director of a department of Arkhangelsk city government, convicted of abuse of power, who illegally granted a piece of land and caused 900 thousand rubles damage to the local budget.

Lately, both the press and the scientific society have energetically been discussing the problem of applying a long-term imprisonment as a punishment to the persons found guilty of corruption. At the same time, the author shares the opinion that in this case, protecting the public from the criminals for some period of time, removing a person from habitual society and placing him in a closed environment, the state does not take any effective measures to reform him (Kornienko, 2010). 
We think that there is another way possible to restore social justice and to use both individual and common preventive measures. In our opinion, it's more reasonable to remove a corrupt official from office for a long term, sometimes for ever, thus depriving him of the opportunity to continue his corruption activity. Besides, in order to restore social justice it's necessary to deprive him of everything "earned with hard work", and in order to reform him to punish him financially by fixing considerable fines.

In case the principle of inevitable punishment for corruption crimes is obeyed, it seems that such measures in relation to corrupt persons will fully correspond with the goals of general and partial prevention, and considerable saving of criminal repression, as well as of finance, spent by the government on imprisoned persons, will let improve essentially the economy by using this money on public purposes.

But with this it's necessary to think of a mechanism to return money in the budget with the help of fines imposed as a punishment on the convicts. By the way, recently this issue was discussed by the Supreme Court as well. The statement adopted by the plenary session of the Supreme Court of the Russian Federation says that a convict is to pay a fine within 30 days after bringing a sentence by the court. Otherwise a convict (when we say about four types of crime- bribe giving, bribe taking, mediation in bribery and commercial bribery) will be considered a defaulter. In this case he will be given another penalty, for instance, 15-year imprisonment stipulated by the RF Criminal Code for "bribery".

The presiding judge, Elena Peisikova, explained that nowadays in the majority of corruption crimes, fines are imposed without any alternative. As "many people were convicted for the first time or for a petty bribe or have dependants.....in the absence of aggravating circumstances can't be sentenced with imprisonment", the judge stresses. Meanwhile, the statistics she read looks depressing." In 2011 46,5\% convicts were imposed fines as a punishment. But during six months of 2013 the number was 78,7\% already." The final accord in the modernization of the Criminal code, which was carried out by the former President Dmitry Medvedev, was played yesterday by the Federal Bailiff Agency. According to it, since last year the bailiffs had in the proceedings fines of 2 billion rubles. Only 155 million was carried out. It made up 7,75\% of the whole sum of fines defined by the courts. In this connection, more severe attitude of the courts towards the convicted bribe-takers who do not pay imposed fines is an absolutely correct measure (Note 5).

When considering issues of applying anti-corruption legislation in Russia one should note a present problem of corruption activity among the law enforcement agencies themselves, i.e. the persons who are initially obliged to fight corruption.

Thus, according to the statistics, over 800 law enforcement officials were convicted for corruption crimes in Russia in 2013. The Head of the General Public Prosecution of the Russian Federation and the Head of the RF Investigating Committee produced the information according to which more than $40 \%$ of all corruption criminal suits brought in Russia fall on the law enforcement agencies. Dmitry Medvedev called this statistics sad and dangerous. "The fact that one third of these crimes is committed by the law enforcement staff is very bad. It demonstrates that the system of law enforcement agencies is infected with corruption not less than the public service", the head of the state noted (Note 6).

But not only Russia faces this problem, even in the developed legal systems of the European states and the USA the problem of obeying the law by the law enforcement employees is very urgent.

In spite of the fact that corruption activity among the law enforcement employees is evident in almost all countries, the information about how the employees of departments fight for "purity" in their staff is seldom made public. However, the facts which are made public witness that in almost any country there is a special agency within the structure of any department, the employees of which investigate offences committed by their colleagues. Thus, for instance, a special service - the Operational Investigative Bureau of the Ministry of Home Affairs- was created by the Interior Minister within the Ministry of Home Affairs. All departments of interior security of the Ministry composed this Bureau. And, in the opinion of analysts, this measure gives definite results. First of all, every year the effectiveness of checking the information from citizens and operative sources about offences committed by the policemen is increasing.

The world experience convinces: professionalism and competence of employees of departments, and ultimately "the purity of ranks" and absence of corruption, directly depend on the quality of selection of candidates for service. With this the main factor, which influences the success of the work done, is maintaining a high level of social prestige of a law enforcement employee.

Besides, a stable and adequate level of welfare as well as the social security of a policeman is absolutely essential. Thus, in France, for example, "faultless service" (in particular, absence of disciplinary punishments for 
corruption activity) provides the right to increased retired benefits. In another turn, the working experience in the police service is excluded (either fully or partially) when calculating the retired benefits as a disciplinary penalty for the offender.

In France and Germany a principle of "transparency of the career" is realized in police service, which gives a person applying for a job an opportunity to evaluate both financial (the level of money provision and retired benefits) and statues (the prestige of the job, social benefits and preferences for the members of the family of an employee) aspects provided for policemen.

There is a world practice of carrying out a special psycho-physiological test for the candidates for police service. And using a polygraph is an ordinary procedure. The questions asked by an expert touch all spheres of a candidate's life. The thoroughness is confirmed by the fact that, e.g. procedure of examining one candidate in the FBI, the US Ministry of Justice, lasts on average 3-4 hours. And a refusal to be exposed to polygraph as well as a refusal to answer some questions of the questionnaire causes an ultimate denial to be taken to service.

In Russia, as the experience of work of interior security agencies demonstrates, in some cases using traditional methods of checking some information does not always allow to establish all circumstances of a crime carefully and impartially. A law enforcement serviceman is a peculiar person who is aware of possible actions towards him and often ready for them. Nevertheless, the potentialities of a polygraph let evaluate psycho-physiological reaction of the people asked on many positions and to deceive it is impossible. In this connection even an excellent knowledge of the tactics and methods of work of the department doesn't provide an opportunity for slyness. For instance, in 2013 during official check-up 10 employees of the law enforcement agencies passed the testing procedure in the department of interior security, while 15 employees failed the test.

A particular condition is the "transparency" of a candidate's welfare. Most departments stipulate presenting special declarations. All given information is accumulated and subjected to regular check-up during all term of service of an employee.

In the Russian Federation the world experience of recruiting accumulated by various departments is not realized in full measure. Nowadays there functions a system of psycho-physiological testing, a system of declaring personal and real property for officials, as well as some property obligations; the same duties are provided for candidates for vacancies in departments.

In the staffing of various departments there functions a system according to which all candidates pass not only staff examination but also an agreement with an appropriate interior security agency. Only during the first six months this year the interior security agencies of the Ministry of Home Affairs carried out over 60 thousand agreements, with negative references for more than 2000 candidates. Annually the number of such persons constitutes 5-6 per cent.

Similar to the Russian model seems the practice to publish in the mass media and on Internet the information about coming appointment of a person to an official post, used in the People's Republic of China. In consequence citizens or policemen (as this information is placed in interior electronic net of Chinese departments as well) within two weeks following this announcement can report a formal statement that they have some evidence able to prevent this coming staff decision.

Taking into consideration the problems that arise during official activity, and examined world experience we suggest actualizing legal basis for functioning of law enforcement agencies with the advanced anti-corruption levers and barriers.

Firstly, to establish a competition as a basis in staffing the employees for law enforcement agencies. The candidates for appointment should be exposed to a special psycho-physiological test (polygraph) in order to define their appropriateness to serve in the departments and to discover possible illegal motivation.

Secondly, it's appropriate to simplify the procedure and to actualize the grounds for dismissal from law enforcement agencies the employees who compromised themselves, in order of attestation as well, for the following:

-refusal to pass a psycho-physiological test, also with the use of polygraph;

-presenting deliberately false personal data;

-violating bans connected with service.

In the third, it is necessary to introduce additional civil guarantees for employees and the members of their families, to raise the salaries of employees and to settle problems with accommodation. 
Realization of all these will allow to raise to a new quality position many issues of anti-corruption security in the law enforcement agencies of the Russian Federation which can considerably be reflected on the statistics of corruption criminal cases, one third of which still falls on the employees themselves.

\section{Conclusion}

To sum up, we'd like to say that it's impossible to get fully rid of corruptive acts but quite real to minimize them directing government efforts to reduction of the latency of such crimes and to creation of situation to prevent corruption.

\section{References}

Corrupion: Fighting arises, bribes are increasing. Коррупция: борьба крепчает, взятка нарастает... Retrieved from jttp://:1//korrossia.ru/actual/10764-korrupciya-borba-krepchaet-vzyatka-narastaet.html

Corruption damage in Russia added to about 21 billion rubles within 10 months. Retrieved from http://m.vedomosti.ru/news/19866671

Damages from corruption deals in Russia for 10 month is about $10 \mathrm{mln}$ roubles. Retrieved from http://m.vedomosti.ru/news/19866671

Grigoriev, N. V. (2009). Do the flaws in the criminal procedure legislation encourage the arbitrariness of officials and corruption? Moscow.

Kornienko, V. T. (2010). How to make the society less corrupted or anti-corruption standards of a municipal corporation. Sledovatel, 10(150), 41.

Kuzenkov, I. L. (2009). Problems in Investigation of Corruption Crimes, Interaction of the Crime Detection Agencies. Problems of Realization National Anti-Corruption Plan in the Far-Eastern Federal District. Theses of Conference 15.06.2009. Khabarovsk. p.111

More than 800 policemen were accused of corruption crimes in 2013 in Russia. Retrieved from http://www.mk.ru/social/news/2014/01/09/968183-svyishe-800-sotrrudnikov-pravoohranitelnyih-organov-o suzhdenyi-v-2013-gody-za-korruptsiyu-v-rf.html.

Nomokonov, V. A. (2009). New Anti-Corruption Law and the Perspectives of Forming Anti-Corruption Policy. Problems of Realization National Anti-Corruption Plan in the Far-Eastern Federal District. Theses of Conference 15.06.2009. Khabarovsk. p.46

The investigation commetee made a report about fighting corruption in state authorities. Retrieved from http://www.rg.ru/2013/12/10/usherb.html

\section{Notes}

Note 1. DOI: 1//korrossia.ru/actual/10764-korrupciya-borba-krepchaet-vzyatka-narastaet.html

Note 2. DOI: www.rg.ru/2013/12/10/usherb.html

Note 3. DOI: m.vedomosti.ru/news/19866671

Note 4. DOI: m.vedomosti.ru/news/19866671

Note 5. DOI: 1//korrossia.ru/actual/10764-korrupciya-borba-krepchaet-vzyatka-narastaet.html

Note 6. DOI: www.mk.ru/social/news/2014/01/09/968183-svyishe-800-sotrudnikov-pravoohranitelnyih-organ ov-osuzhdenyi-v-2013-gody-za-korruptsiyu-v-rf.html.

\section{Copyrights}

Copyright for this article is retained by the author(s), with first publication rights granted to the journal.

This is an open-access article distributed under the terms and conditions of the Creative Commons Attribution license (http://creativecommons.org/licenses/by/3.0/). 